\title{
Home Environment of Late Adolescent Boys and Girls Belonging to Joint Family in Udaipur city, India
}

\author{
L. Sati ${ }^{1}$ and S. Gir \\ Department of Human Development and Family Studies, College of H.Sc., MPUAT, Udaipur, India
}

\begin{abstract}
The present study was an attempt to assess and compare the home environment of late adolescent boys and girls residing in joint family. The total sample for the present study consisted of 120 late adolescent boys and girls. The sample was selected from 6 non coeducational government schools of Udaipur city. A preliminary survey was conducted among $11^{\text {th }}$ and $12^{\text {th }}$ class students to select the sample as per the delimitation of the study. Home environment inventory was administered to assess home environment. The data was collected, coded and analyzed. Frequency and percentage was computed for each category.
\end{abstract}

KEYWORDS: Home environment, Joint family, Negative Parenting Behavior, Neutral Parenting Behavior, Positive Parenting Behavior

\section{INTRODUCTION}

Adolescence is a period of marked change in the person's cognitive, physical, psychological, and social development and in the individual's relations with the people and institutions of the social world. Adolescents face many problems of demands, uncertainties and competition. Majed and Fatema (2009) evaluated the difference and relationships between stress with aggression, social anxiety and social skills across adolescents of Kuwait and Indian samples. It was found that the level of stress among Indian adolescents is higher than those of Kuwait, because of the surrounding environment of the sample of India facing many economical and sociological problems. It is important developmental phase along the path to adulthood, years during which youth become increasingly independent from their families. Yet parents and other family members still play a critical role in the promotion of adolescents' well-being, by providing a positive support system within which youth can explore their changing identity. Aneesa, Najma and Noreen (2013) explored that good family communication supports good family functioning leading to satisfaction among the adolescents. Adolescents with high control, social isolation, deprivation of privileges and rejection at home have shown significantly lower problem solving, decision making, coping with emotion, coping with stress and overall psychosocial competence. Children with high protectiveness, punishment, conformity, reward, nurturance and permissiveness have better empathy, critical thinking, empathy, self-awareness, coping with stress, interpersonal relations and effective communication as well as overall psychosocial competence. Findings of this study reveal the significance of home environment in the development of life skills. Decline in the prevalence of the traditional family is frequently cited as a potential cause of many of the current problems that plaque adolescents such as poor educational outcome, drug abuse, juvenile delinquency, frustration, depression etc. Family being the first and major agency of socialization serves as an effective agent of socialization - a process of growing up and learning the norms of society, where an adolescent acquires a few workable assumptions about the world and is apt to become a competent and useful member of society. Singh et al. (2014) in a study titled "Impact of family structure on social and emotional maturity of adolescents" observes that adolescents from joint family were more personally, interpersonally and socially adequate and thus, socially mature. Similarly, they were significantly higher on emotional stability, emotional progression, social adjustment, personality integration and independence component of emotional maturity than those from nuclear family. Bandhana and Sharma (2012) results revealed that the students with high home environment have higher level of reasoning ability in comparison to one's having low home environment.

\section{OBJECTIVES}

The present was an attempt to assess and compare the home environment of late adolescent boys and girls belonging to joint family as perceived by the adolescents.

\section{METHODOLOGY}

For the sample selection, firstly the list of non-coeducational government schools was procured from District Education Officer. After sorting out non coeducational Government schools from the obtained list, 6 
schools ( 3 for boys and 3 for girls) were sort listed from urban area of Udaipur city. These schools were selected as they were approachable and the school authorities were ready to cooperate.

The total sample for the present study was 240 unmarried adolescents between the age range of 16 to 18 years, studying in non-coeducational government schools of Udaipur city within its municipal limits.

\section{Adolescents (16 to 18 years i.e. Late Adolescents)}

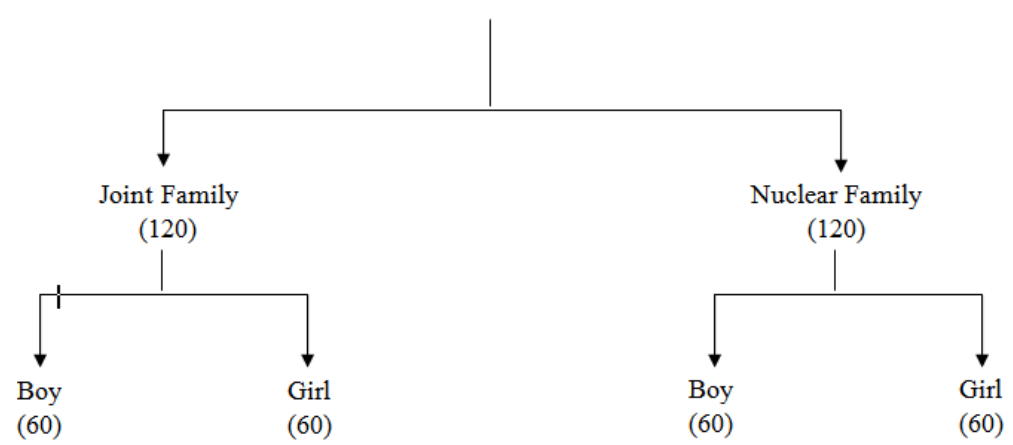

A preliminary survey was conducted among $11^{\text {th }}$ and $12^{\text {th }}$ class students to select sample as per the delimitation of the study.

Information regarding selection of sample

\begin{tabular}{|l|l|l|l|l|}
\hline S. No. & \multicolumn{1}{|c|}{ Description } & Boys & Girls & Total Number \\
\hline 1 & Preliminary performa (Distributed) & 171 & 179 & 350 \\
\hline 2 & Preliminary performa (Received back) & 171 & 179 & 350 \\
\hline 3 & Eligible subjects & 138 & 142 & 280 \\
\hline 4 & Sample drawn (Randomly) & 120 & 120 & 240 \\
\hline
\end{tabular}

For the purpose of assessment of home environment, home environment inventory developed by Mishra (1989) was administered. Home Environment Inventory is an instrument designed to measure the psychosocial climate of home as perceived by children. It provides a measure of the quality and quantity of the cognitive, emotional and social support that has been available to the child within the home. HEI has 100 items belonging to ten dimensions of home environment. The ten dimensions are (A) Control, (B) Protective (C) Punishment (D) Conformity (E) Social isolation (F) Reward (G) Deprivation of privileges (H) Nurturance (I) Rejection and (J) Permissiveness. Each dimension has ten items belonging to it. The instruments requires pupils to tell the frequency with which a particular parent - child interaction behavior has been observed by them in their homes i.e. he/she is requested to tell whether a particular parental behavior (as mentioned in an item) occurs- 'Mostly', 'Often', 'Sometimes', 'Least', and 'Never,'. There is no time limit for this tool, but on an average participant took 30 minutes to complete the tool. The tool being in Hindi was attempted easily without any problem.

\section{ANALYSIS OF DATA}

The subjects each answer was given the score with the help of 5point scale ranging from 4 to 0.4 score to 'Mostly', 3 score to 'Often', 2 score to 'Sometimes', 1score to 'Least', and 0 score to 'Never' responses. The data was decoded and analyzed by using frequency and percentage.

\section{RESULTS AND DISCUSSION}

Data in Table 1 depicts that in joint families level of protectiveness, conformity, reward, and nurturance were found to be same for both the sexes. Adolescents are at the doorstep of risky behavior which has serious negative consequences and 51 percent of adolescent claimed that they like to spend time with family (Mishra 2006). This shows parents are following positive parenting style to maintain good home environment which is necessary for the healthy development of the adolescents (Bandhana and Sharma 2012). To protect the adolescents from risky behavior parents protect them by trying to organize their abilities, needs, interest, and desires so that these all can be expressed in a social context and hence level of conformity is also same. In joint families generally individuality is not much reinforced and rewards to individual are given on very rare and 
great achievement. That may be the reason for same level of reward. The reason for similar level of nurturance can be attributed to multiple parenting i.e. number of elderly figures is more and hence better nurturance.

Table 1: Percentage distribution of sample for the their perception of positive parental childrearing behavior in the context of gender $(\mathrm{N}=120)$

\begin{tabular}{|c|c|c|c|c|c|c|c|}
\hline \multirow{2}{*}{$\begin{array}{c}\text { Positive } \\
\text { Parenting } \\
\text { Behavior }\end{array}$} & \multirow[b]{2}{*}{ Categories } & \multicolumn{2}{|c|}{ Gender } & \multirow{2}{*}{$\begin{array}{l}\text { Positive } \\
\text { Parenting } \\
\text { Behavior }\end{array}$} & \multirow{2}{*}{$\begin{array}{c}\text { Categorie } \\
s\end{array}$} & \multicolumn{2}{|c|}{ Gender } \\
\hline & & $\begin{array}{c}\text { Boys } \\
(n=60)\end{array}$ & $\begin{array}{c}\text { Girls } \\
(n=60)\end{array}$ & & & $\begin{array}{c}\text { Boys } \\
(n=60)\end{array}$ & $\begin{array}{c}\text { Girls } \\
(n=60)\end{array}$ \\
\hline \multirow{6}{*}{$\begin{array}{c}\text { Protective } \\
\text { ness }\end{array}$} & $\mathbf{A}$ & $\begin{array}{l}5(8.33 \% \\
)\end{array}$ & $\begin{array}{l}4(6.66 \% \\
)\end{array}$ & \multirow{6}{*}{ Reward } & $\overline{\mathbf{A}}$ & $\begin{array}{l}6 \\
(10.00 \\
\%)\end{array}$ & $\begin{array}{l}5 \\
(8.33 \% \\
)\end{array}$ \\
\hline & B & $\begin{array}{l}8 \\
(13.33 \% \\
)\end{array}$ & $\begin{array}{l}9 \\
(15.00 \% \\
)\end{array}$ & & B & $\begin{array}{l}8 \\
(13.00 \\
\%)\end{array}$ & $\begin{array}{l}10 \\
(16.66 \\
\%)\end{array}$ \\
\hline & $\mathbf{C}$ & $\begin{array}{l}13 \\
(21.66 \% \\
)\end{array}$ & $\begin{array}{l}15 \\
(25.00 \% \\
)\end{array}$ & & $\mathrm{C}$ & $\begin{array}{l}15 \\
(25.00 \\
\%)\end{array}$ & $\begin{array}{l}13 \\
(21.66 \\
\%)\end{array}$ \\
\hline & D & $\begin{array}{l}18 \\
(30.00 \% \\
)\end{array}$ & $\begin{array}{l}16 \\
(26.66 \% \\
)\end{array}$ & & D & $\begin{array}{l}15 \\
(25.00 \\
\%)\end{array}$ & $\begin{array}{l}16 \\
(26.66 \\
\%)\end{array}$ \\
\hline & $\mathbf{E}$ & $\begin{array}{l}10 \\
(16.66 \% \\
)\end{array}$ & $\begin{array}{l}9 \\
(15.00 \% \\
)\end{array}$ & & $\mathbf{E}$ & $\begin{array}{l}10 \\
(16.66 \\
\%)\end{array}$ & $\begin{array}{l}10 \\
(16.66 \\
\%)\end{array}$ \\
\hline & $\mathbf{F}$ & $\begin{array}{l}6 \\
(10.0 \%)\end{array}$ & $\begin{array}{l}7 \\
(11.66 \% \\
)\end{array}$ & & $\mathbf{F}$ & $\begin{array}{l}6 \\
(10.00 \\
\%) \\
\end{array}$ & $\begin{array}{l}6(10.00 \\
\%)\end{array}$ \\
\hline \multirow{6}{*}{$\begin{array}{c}\text { Conformit } \\
\mathbf{y}\end{array}$} & $\mathbf{A}$ & $\begin{array}{l}4 \\
(6.66 \%)\end{array}$ & $\begin{array}{l}4 \\
(6.66 \%)\end{array}$ & \multirow{6}{*}{$\begin{array}{c}\text { Nurturan } \\
\text { ce }\end{array}$} & $\mathbf{A}$ & $\begin{array}{l}4 \\
(6.66 \%\end{array}$ & $\begin{array}{l}5 \\
(8.33 \%\end{array}$ \\
\hline & B & $\begin{array}{l}11 \\
(18.33 \% \\
)\end{array}$ & $\begin{array}{l}11 \\
(18.33 \% \\
)\end{array}$ & & B & $\begin{array}{l}6 \\
(10.00 \\
\%)\end{array}$ & $\begin{array}{l}7 \\
(11.66 \\
\%)\end{array}$ \\
\hline & $\mathbf{C}$ & $\begin{array}{l}15 \\
(25.00 \% \\
)\end{array}$ & $\begin{array}{l}10 \\
(16.66 \% \\
)\end{array}$ & & $\mathbf{C}$ & $\begin{array}{l}19 \\
(31.66 \\
\%)\end{array}$ & $\begin{array}{l}13 \\
(21.66 \\
\%)\end{array}$ \\
\hline & D & $\begin{array}{l}15 \\
(25.00 \% \\
)\end{array}$ & $\begin{array}{l}20 \\
(33.33 \% \\
)\end{array}$ & & D & $\begin{array}{l}14 \\
(23.33 \\
\%) \\
\end{array}$ & $\begin{array}{l}18 \\
(30.00 \\
\%)\end{array}$ \\
\hline & $\mathbf{E}$ & $\begin{array}{l}9 \\
(15.00 \% \\
)\end{array}$ & $\begin{array}{l}9 \\
(15.00 \% \\
)\end{array}$ & & $\mathbf{E}$ & $\begin{array}{l}11 \\
(18.33 \\
\%)\end{array}$ & $\begin{array}{l}12 \\
(20.00 \\
\%)\end{array}$ \\
\hline & $\mathbf{F}$ & $\begin{array}{l}6 \\
(10.00 \% \\
)\end{array}$ & $\begin{array}{l}6(10.00 \\
\%)\end{array}$ & & $\mathbf{F}$ & $\begin{array}{l}6 \\
(10.00 \\
\%)\end{array}$ & $\begin{array}{l}5 \\
(8.33 \% \\
)\end{array}$ \\
\hline
\end{tabular}

Data in Table 2 depicts that inall negative parenting behaviors were found to be higher for girls as compared to boys i.e. Deprivation of privilege, punishment, rejection, and social isolation. The results inline with research conducted by Parmer (2014) on various dimension of home environment among higher secondary school students in relation to gender. Girls receive more punishment the reason may be the traditional stereotyped families who expect more from girls regarding their traits, roles, responsibilities, and obligation. Hence girls are portrayed as symbol of perfection. Social isolation was found to be higher may be due to the reason that girls are considered as representation of families' social status. So the security and protection of girls is very important. So they don't get exploited. Girls were deprived of privilege because of traditional patriarchal family where males are more valued as compared to girls. Rejection was more due to prevalence of traditional patriarchal families where higher demands are placed on female about their role, responsibilities, traits etc. Decisions are generally made for them they have no identity as an individual, no right to express their feelings, uniqueness or to develop autonomy. If they try to move towards one of these human longings than they are rejected. 
Table 2: Percentage distribution of sample for the their perception of negative parental childrearing behavior in the context of gender $(\mathrm{N}=120)$

\begin{tabular}{|c|c|c|c|c|c|c|c|}
\hline \multirow{2}{*}{$\begin{array}{l}\text { Negative } \\
\text { Parenting } \\
\text { Behavior }\end{array}$} & \multirow{2}{*}{ Categories } & \multicolumn{2}{|c|}{ Gender } & \multirow{2}{*}{$\begin{array}{l}\text { Positive } \\
\text { Parenting } \\
\text { Behavior }\end{array}$} & \multirow{2}{*}{ Categories } & \multicolumn{2}{|c|}{ Gender } \\
\hline & & $\begin{array}{c}\text { Boys } \\
(n=60)\end{array}$ & $\begin{array}{c}\text { Girls } \\
(n=60)\end{array}$ & & & $\begin{array}{c}\text { Boys } \\
(n=60)\end{array}$ & $\begin{array}{c}\text { Girls } \\
(n=60)\end{array}$ \\
\hline \multirow{6}{*}{ Punishment } & $\mathbf{A}$ & $\begin{array}{l}6 \\
(10.00 \%)\end{array}$ & $\begin{array}{l}6 \\
(10.00 \%)\end{array}$ & \multirow{6}{*}{$\begin{array}{c}\text { Deprivation } \\
\text { of } \\
\text { privileges }\end{array}$} & $\mathbf{A}$ & $\begin{array}{l}5 \\
(8.33 \%) \\
\end{array}$ & $\begin{array}{l}6 \\
(10.00 \%)\end{array}$ \\
\hline & $\mathbf{B}$ & $\begin{array}{l}9 \\
(15.00 \%)\end{array}$ & $\begin{array}{l}8 \\
(13.33 \%)\end{array}$ & & B & $\begin{array}{l}8 \\
(13.33 \%)\end{array}$ & $\begin{array}{l}9 \\
(15.00 \%)\end{array}$ \\
\hline & $\mathbf{C}$ & $\begin{array}{l}15 \\
(25.00 \%)\end{array}$ & $\begin{array}{l}12 \\
(20.00 \%)\end{array}$ & & $\mathbf{C}$ & $\begin{array}{l}15 \\
(25.00 \%)\end{array}$ & $\begin{array}{l}14 \\
(23.33 \%)\end{array}$ \\
\hline & D & $\begin{array}{l}11 \\
(18.33 \%)\end{array}$ & $\begin{array}{l}17 \\
(28.33 \%)\end{array}$ & & D & $\begin{array}{l}13 \\
(21.66 \%)\end{array}$ & $\begin{array}{l}13 \\
(21.66 \%)\end{array}$ \\
\hline & $\mathbf{E}$ & $\begin{array}{l}13 \\
(21.66 \%)\end{array}$ & $\begin{array}{l}11 \\
(18.33 \%)\end{array}$ & & $\mathbf{E}$ & $\begin{array}{l}14 \\
(23.33 \%) \\
\end{array}$ & $\begin{array}{l}12 \\
(20.00 \%)\end{array}$ \\
\hline & $\mathbf{F}$ & $\begin{array}{l}6 \\
(10.00 \%)\end{array}$ & $\begin{array}{l}6 \\
(10.00 \%)\end{array}$ & & $\mathbf{F}$ & $\begin{array}{l}5 \\
(8.33 \%) \\
\end{array}$ & $\begin{array}{l}6 \\
(10.00 \%)\end{array}$ \\
\hline \multirow{6}{*}{$\begin{array}{c}\text { Social } \\
\text { isolation }\end{array}$} & $\mathbf{A}$ & $\begin{array}{l}6 \\
(10.00 \%)\end{array}$ & $\begin{array}{l}6 \\
(10.00 \%)\end{array}$ & \multirow{6}{*}{ Rejection } & $\mathbf{A}$ & $\begin{array}{l}6 \\
(10.00 \%)\end{array}$ & $\begin{array}{l}6 \\
(10.00 \%)\end{array}$ \\
\hline & $\mathbf{B}$ & $\begin{array}{l}8 \\
(13.33 \%)\end{array}$ & $\begin{array}{l}8 \\
(13.33 \%)\end{array}$ & & $\mathbf{B}$ & $\begin{array}{l}7 \\
(11.66 \%)\end{array}$ & $9(15 \%)$ \\
\hline & $\mathbf{C}$ & $\begin{array}{l}16 \\
(26.66 \%)\end{array}$ & $\begin{array}{l}15 \\
(25.00 \%)\end{array}$ & & $\mathbf{C}$ & $\begin{array}{l}17 \\
(28.33 \%)\end{array}$ & $\begin{array}{l}13 \\
(21.66 \%)\end{array}$ \\
\hline & D & $\begin{array}{l}13 \\
(21.66 \%)\end{array}$ & $\begin{array}{l}16 \\
(26.66 \%)\end{array}$ & & D & $\begin{array}{l}14 \\
(23.33 \%)\end{array}$ & $\begin{array}{l}17 \\
(28.33 \%)\end{array}$ \\
\hline & $\mathbf{E}$ & $\begin{array}{l}12 \\
(20.00 \%)\end{array}$ & $\begin{array}{l}10 \\
(16.66 \%)\end{array}$ & & $\mathbf{E}$ & $\begin{array}{l}10 \\
(16.66)\end{array}$ & $\begin{array}{l}9 \\
(15.00 \%)\end{array}$ \\
\hline & $\mathbf{F}$ & $\begin{array}{l}5 \\
(8.33 \%)\end{array}$ & $\begin{array}{l}5 \\
(8.33 \%)\end{array}$ & & $\mathbf{F}$ & $\begin{array}{l}6 \\
(10.00 \%)\end{array}$ & $\begin{array}{l}6 \\
(10.00 \%)\end{array}$ \\
\hline
\end{tabular}

$\mathrm{A}=$ Excellent, $\mathrm{B}=\mathrm{Good}, \mathrm{C}=$ Fair, $\mathrm{D}=$ Average, $\mathrm{E}=$ Poor, $\mathrm{F}=$ Very Poor

From Table 3 it was found that in joint families level of control was high for girls as compared to boys because it will help to foster reserved nature of girls, so that she can be socially accepted i.e. better socialized. Similarly, Parmer (2014) reported in his study that females are controlled more at home as compared to boys. Permissiveness was same for both the sexes. The results inline with the study conducted by Rapheal et al 2014 in which they found no significant gender difference in the perceived permissiveness.

Table 3: Percentage distribution of sample for their perception of neutral parental childrearing behavior in the context of gender $(\mathrm{N}=120)$

\begin{tabular}{|c|c|c|c|c|c|c|c|}
\hline \multirow{2}{*}{$\begin{array}{c}\text { Neutral } \\
\text { Parentin } \\
g \\
\text { Behavio } \\
r\end{array}$} & \multirow{2}{*}{$\begin{array}{c}\text { Categori } \\
\text { es }\end{array}$} & \multicolumn{2}{|c|}{ Gender } & \multirow{2}{*}{$\begin{array}{l}\text { Neutral } \\
\text { Parenting } \\
\text { Behavior }\end{array}$} & \multirow{2}{*}{$\begin{array}{l}\text { Categori } \\
\quad \text { es }\end{array}$} & \multicolumn{2}{|c|}{ Gender } \\
\hline & & $\begin{array}{c}\text { Boys } \\
(n=60)\end{array}$ & $\begin{array}{c}\text { Girls } \\
(n=60)\end{array}$ & & & $\begin{array}{c}\text { Boys } \\
(n=60)\end{array}$ & $\begin{array}{c}\text { Girls } \\
(n=60)\end{array}$ \\
\hline \multirow{5}{*}{ Control } & $\overline{\mathbf{A}}$ & $\begin{array}{l}4 \\
(6.66 \%)\end{array}$ & $4(6.66 \%)$ & \multirow{5}{*}{$\begin{array}{c}\text { Permissiven } \\
\text { ess }\end{array}$} & $\bar{A}$ & $6(10.00 \%)$ & $\begin{array}{l}6 \\
(10.00 \%)\end{array}$ \\
\hline & $\mathbf{B}$ & $\begin{array}{l}9 \\
(15.00 \\
\%)\end{array}$ & $\begin{array}{l}13 \\
(21.66 \%)\end{array}$ & & B & $8(13.33 \%)$ & $\begin{array}{l}8 \\
(13.33 \%)\end{array}$ \\
\hline & $\mathbf{C}$ & $\begin{array}{l}17 \\
(28.33 \\
\%)\end{array}$ & $\begin{array}{l}14 \\
(23.33 \%)\end{array}$ & & $\mathbf{C}$ & $12(20.00 \%)$ & $\begin{array}{l}14 \\
(23.3 \%)\end{array}$ \\
\hline & D & $\begin{array}{l}13 \\
(21.66 \\
\%)\end{array}$ & $\begin{array}{l}13 \\
(21.66 \%)\end{array}$ & & D & $19(31.66 \%)$ & $\begin{array}{l}17 \\
(28.33 \%)\end{array}$ \\
\hline & $\mathbf{E}$ & $\begin{array}{l}11 \\
(18.33\end{array}$ & $\begin{array}{l}10 \\
(16.66 \%)\end{array}$ & & $\mathbf{E}$ & $9(15.00 \%)$ & $\begin{array}{l}10 \\
(16.66 \%)\end{array}$ \\
\hline
\end{tabular}




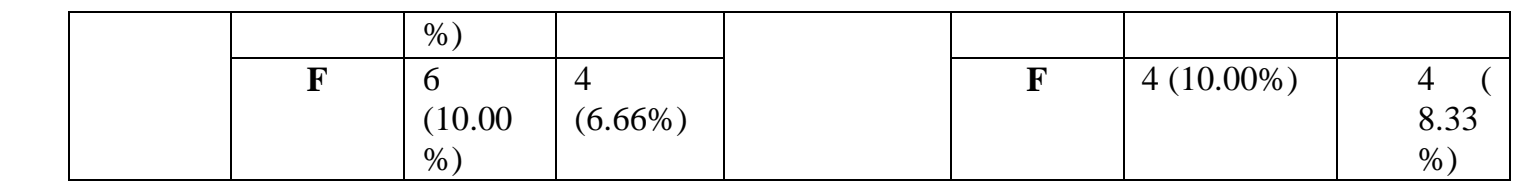

$\mathrm{A}=$ Excellent, $\mathrm{B}=$ Good, $\mathrm{C}=$ Fair, $\mathrm{D}=$ Average, $\mathrm{E}=$ Poor, $\mathrm{F}=$ Very poor

\section{RECOMMENDATIONS}

Further research can be focus on other age groups and various setting of schools like coeducational, non coeducational setting and government and private schools.

\section{CONCLUSION}

So it can be concluded that parents have understood role of positive parenting but at the same time they are unable to overcome the stereotypic gender discrimination which can be clearly seen in the way how they treat boys and girls differently.

\section{REFERENCES}

[1] Aneesa A, Najma M and Noreen A 2013. Family Communication and Family System as the Predictors of Family Satisfaction in Adolescents. Science Journal of Psychology, 13(6): 253-258.

[2] Bandhana and Sharma P D (2012). A Study of Home Environment and Reasoning Ability among Secondary School Students. International Journal of Scientific and Research Publications, 2 (5),ISSN 2250-3153.

[3] Majed A and Fatema B 2010. Prejudice in relation to aggression, stress and self confidence among, school adolescents. Journal of Health and Illness, 1: 93-101.

[4] Mishra A K 2006. Need Assessment of adolescents in Bageshwar District Uttaranchal. Indian Journal of Population Education, 26-35.

[5] Mishra S K 1989. Manual of Home Environment Inventory. National psychological corporation. Agra.

[6] Parmer R N 2014. A Study of Various Dimensions of Home Environment among Higher Secondary School Students in relation to Gender. International Journal for technological Research in Engineering, 1(7): 497-500.

[7] Rapheal J, Damodar D K and Varghese P K 2014. Home Environment as perceived by adolescents of kerala. International Research Journal of Social Science, 3(10): 38-45

[8] Singh R, Pant K, and Valentina L (2014). Impact Analysis- Family Structure on Social and Emotional Maturity of Adolescents. Anthropologist, 17(2): 359-365. 